\title{
Studies on insecticidal and pesticidal activity of some organotin compounds
}

\author{
Shukla S.K. ${ }^{1}$, Tiwari V.K. ${ }^{1}$, Rani S. ${ }^{2}$, Ravi Kant ${ }^{3}$, Tewari I.C. ${ }^{{ }^{*}}$ \\ ${ }^{1}$ Department of Chemistry, D. B. S. College, Kanpur, India, 208006 \\ ${ }^{2}$ Department of Chemistry, D. G. (P.G) College, Kanpur, India, 208001 \\ ${ }^{3}$ Department of Medicinal Chemistry, Mahatma Gandhi Institute of Pharmacy, Lucknow, India, 227101
}

\begin{abstract}
A series of new triorganotin compounds were synthesized and tested first time for their insecticidal and pesticidal activity against Periplanata americana, Musca domestica and Spodoptera litura and Tetranichus urticae of a pest crop mite and were found highly active against Spodoptera litura. It was found that these insects and pest highly damage the Indian crops and ultimately economy also.
\end{abstract}

Key words: Organotin(IV)amide, insecticidal, pesticidal, antifeedant and acaricidal activity.

\section{Introduction}

It is well known that the studies on insect and pest behavior and their control are collectively proceeds in entomology [1]. Insects are found in almost all types of environment. They affect man's interest in a number of ways; insects like mosquitoes and housefly spread large number of diseases like malaria, dengue and cholera in addition to painful bites. However, all insects are not harmful; some are beneficial such as honey bee which give us honey and silk worm which provide us silk. Insecticide is mainly a substance intended for killing, repelling or otherwise preventing treated surface from insects [2]. The use of insecticides started with the discovery of Paris green [3], which was a synthetic compound of arsenic, in 1867 to control the colorado potato beetle. Until 1939, most of the insecticides were inorganic chemicals [4]. There are a large number of organic [5] and metal organic [6] compounds as insecticides which have made revolutionary change in the field of chemical control. The phenolics [7] and carbamates [8] are the major organic derivatives used as potent insecticides. But later on the introduction of metal based organic derivatives as insecticides made a new revolution in entomology. Organotin derivatives have emerged as potential biologically active compounds in last $15-20$ years. The spectrum of the chemotherapeutic values of organotin compounds has been expanded as they have found their place among a class of potential biologically active compounds [9] exhibiting antimicrobial activity against different kinds of microbial strains [10]. They also show anti-inflammatory and cardiovascular activity [11], trypanosomal activity [12] along with anti-herpes [13] and anti-tubercular activity [14]. In case of control of insect and pest organotin compounds are not much explored because of their solubility reasons. In order to make this kind of compounds more soluble in water, less complicated structure was designed which contains polar moieties [15]. The introduction of polar groups in the organotin molecules leads to some improvement in the solubility and efficacy of activity. Fluorine containing compounds are more soluble in water and still very soluble in non-polar solvents [16]. The solubility can also be increased by preparing salts of organotin compounds [17]. In the present communication a series of new triorganotin compounds were synthesized and tested first time for their insecticidal and pesticidal activity against Periplanata americana, Musca domestica and Spodoptera litura and Tetranichus urticae of a pest crop mite and were found highly active against Spodoptera litura.

\section{Experimental}

The synthesis of organotin compounds was carried out by the earlier reported method [18]. The tetraorganotin compound as a base material can be synthesized by the reaction of respective haloarene with tin tetra chloride and sodium metal in inert atmosphere. The preparation of triorganotin (IV) chloride was takes place by cleavage of the base material with anhydrous tin tetra chloride by fixing an air condenser without using any solvent and the reaction temperature is maintained at $205-215^{\circ} \mathrm{C}$ for one hour and then $180^{\circ} \mathrm{C}$ temperature was maintained for a period of one and half hour. The compounds isolated in pet-ether and recrystalized with the same solvents.

$$
\begin{array}{ccc}
4 \mathrm{R}-\mathrm{X}+\mathrm{SnCl}_{4}+8 \mathrm{Na} & \text { Toluene/Benzene } & \\
\mathrm{R}_{4} \mathrm{Sn}+\mathrm{SnCl}_{4} \stackrel{205-215^{\circ} \mathrm{C} / 180^{\circ} \mathrm{C}}{\longrightarrow} & \mathrm{R}_{4} \mathrm{Sn}+4 \mathrm{NaX}+4 \mathrm{NaCl} \\
\mathrm{R}_{3} \mathrm{SnCl}+\mathrm{HL} & \mathrm{R}_{3} \mathrm{SnCl}+\mathrm{R}_{3} \mathrm{~N} & \\
& \mathrm{R}_{3} \mathrm{SnL}+\mathrm{Et}_{3} \mathrm{~N} \cdot \mathrm{HCl}
\end{array}
$$

$\mathrm{R}=$ (C6H5), (C6F5), (C6H4F), HL = Succinimide, Phthalimide

The preparation of triorganotin (IV) amides was carried out by the reaction of $\mathrm{R} 3 \mathrm{SnCl}$ and suitable amide in presence of triethylamine, as $\mathrm{HCl}$ acceptor, at room temperature under nitrogen atmosphere. The method of preparation of some representative compounds is as follows. Reaction of $(\mathrm{C} 6 \mathrm{H} 5) 3 \mathrm{SnCl}$ with Succinimide In an oxygen free nitrogen atmosphere, solution of triphenyltin (IV) chloride $(0.385 \mathrm{gm} ; 1 \mathrm{mmol})$ in benzene and succinimide $(0.099 \mathrm{gm} ; 1 \mathrm{mmol})$ in same solvent were stirred together in presence of 
triethylamine at room temperature for 4-5 hours. The off white color Et3N. $\mathrm{HCl}$ formed was filtered off and filtrate on evaporation in vaccum gives an off white colour crystaline solid mass which was further recrystalised in pet.ether.

\section{Reaction of (C6H5)3SnCl with Phthalimide}

In an oxygen free nitrogen atmosphere, solution of triphenyltin (IV) chloride $(0.385 \mathrm{gm} ; 1 \mathrm{mmol})$ in benzene and phthalimide $(0.147 \mathrm{gm} ; 1 \mathrm{mmol})$ in same solvent were stirred together in presence of triethylamine at room temperature for 4-5 hours. The off white color Et3N.HCl formed was filtered off and filtrate on evaporation in vaccum gives an off white colour crystaline solid mass which was further recrystalised in pet.ether.

\section{Reaction of (C6F5)3SnCl with Succinimide}

In an oxygen free nitrogen atmosphere, solution of tris (pentafluorophenyl) tin (IV) chloride $(0.655 \mathrm{gm} ; 1 \mathrm{mmol})$ in benzene and succinimide $(0.099 \mathrm{gm} ; 1 \mathrm{mmol})$ in same solvent were stirred together in presence of triethylamine at room temperature for 4-5 hours. The off white color Et3N.HCl formed was filtered off and filtrate on evaporation in vaccum gives an off white colour crystaline solid mass which was further recrystalised in pet.ether.

\section{Reaction of (C6F5)3SnCl with Phthalimide}

In an oxygen free nitrogen atmosphere, solution of tris (pentafluorophenyl) tin (IV) chloride $(0.655 \mathrm{gm} ; 1 \mathrm{mmol})$ in benzene and phthalimide $(0.147 \mathrm{gm} ; 1 \mathrm{mmol})$ in same solvent were stirred together in presence of triethylamine at room temperature for 4-5 hours. The off white color Et3N. $\mathrm{HCl}$ formed was filtered off and filtrate on evaporation in vaccum gives an off white colour crystaline solid mass which was further recrystalised in pet.ether.

\section{Reaction of (C6H4F)3SnCl with Phthalimide}

In an oxygen free nitrogen atmosphere, solution of tris (p-fluorophenyl) tin (IV) chloride $(0.439 \mathrm{gm}$; $1 \mathrm{mmol})$ in benzene and phthalimide $(0.147 \mathrm{gm}$; $1 \mathrm{mmol}$ ) in same solvent were stirred together in presence of triethylamine at room temperature for 4-5 hours. The off white color Et3N. HCl formed was filtered off and filtrate on evaporation in vaccum gives an off white colour crystaline solid mass which was further recrystalised in pet.ether.

\section{Reaction of (C6H4F)3SnCl with Succinimide}

In an oxygen free nitrogen atmosphere, solution of tris (p-fluorophenyl) tin (IV) chloride $(0.439 \mathrm{gm}$; $1 \mathrm{mmol}$ ) in benzene and succinimide (0.099gm; $1 \mathrm{mmol}$ ) in same solvent were stirred together in presence of triethylamine at room temperature for 4-5 hours. The off white color Et3N. HCl formed was filtered off and filtrate on evaporation in vaccum gives an off white colour crystaline solid mass which was further recrystalised in pet.ether.

\section{Insecticidal Activity}

The insecticidal activity of these compounds was determined against male and female cockroaches (Periplanata americana) and housefly (Musca domestica) following the method of Nash [19], using acetone as a standard. The $0.1 \%$ and $0.5 \%$ acetone solution of the compounds were injected between 4th and 5th abdominal segment on the ventral side of the body in cockroaches and sprays on the colony of housefly using microsyrings. A $0.02 \mathrm{ml}$ of acetone was alone injected for control (standard). The treated insects were kept under observation for $48 \mathrm{hrs}$ at room temperature (No food was given in this period and their knock down value is calculated.

\section{Contact Toxicity}

The contact toxicity of these compounds was carried out by topical application method [20] against larvae of Spodoptera litura, which is harmful for Indian crops. First the given compounds were dissolved in acetone and different concentrations were prepared viz., $0.06 \%, 0.12 \%, 0.25 \%, 0.50 \%$, and $1.00 \%$. Now each concentration was applied on the dorsal surface of the larvae of insect. About $10 \square \mathrm{l}$ of each concentration was applied on each larvae. Some of the larvae of insect was treated by acetone alone, were works as control. Now the mortality data was recorded after $24 \mathrm{hrs}$, and the treated mortality was corrected with control morality. These corrected mortality data was used for calculation of LC50/LD50 using Maximum Likelihood programme MLP 3.01.

\section{Stomach Toxicity}

The stomach toxicity of these compounds was carried out by leaf dip method [21]. In this method we used fourth instar larvae of Spodoptera litura of an insect which is responsible for the damage of Indian agricultural crops. Ten larvae were used for each replication and three replications were maintained for each concentration. The given compounds were dissolved in acetone and different concentrations were prepared viz. $0.06 \%, 0.12 \%, 0.25 \%, 0.50 \%$, and $1.00 \%$. The leaf disc were prepared out of caster leaf and dipped in various concentrations of the test compounds for thirty seconds. Now air dried the leaf discs to evaporate the excess acetone. (The leaf discs dipped only in acetone were served as control). The mortality data was recorded after 24 $\mathrm{hrs}$, and the treatment mortality was corrected with control mortality. These mortality data was used for calculation of LC50/LD50 7 using maximum likelihood programm, MLP 3.01.

\section{Antifeedant Activity}

The antifeedant activity of these compounds was also carried out by leaf dip method [21] using fourth instar larvae of Spodoptera litura, an insect 
responsible for the damage of Indian agricultural crops. There are ten larvae were used for each replications and three replications were maintained for each concentration. The given compounds were dissolved in acetone and different concentrations were prepared viz. $0.06 \%, 0.12 \%, 0.25 \%, 0.50 \%$ and $1.00 \%$. The leaf discs of about $25 \mathrm{~cm} 2$ were prepared and dipped for thirty seconds in various concentrations of the test compounds. Now air dried the leaf discs to evaporate the excess acetone and the leaf discs offered for feeding. The insects were allowed to feed for $24 \mathrm{hrs}$. After $24 \mathrm{hrs}$ leaf area uneaten was measured by using leaf area meter. The differences between leaf area provided and the leaf area uneaten is taken as amount of leaf area consumed. The feeding inhibition was calculated and used for calculation of effective concentration (EC50/LD50) using Maximum likelihood programme, MLP 3.01.

\section{Acaricidal Activity}

The acaricidal activity of these compounds was carried out by leaf dip method [21]. Compounds was dissolved in Acetone and different concentrations were prepared viz. $0.001 \%$, $0.005 \%, 0.05 \%, 0.1 \%, 0.5 \%$ using $0.2 \%$ tween 20 as emulsifier. Leaf discs of Mulberry $(5 \mathrm{~cm} 2$ diameter) were dipped in different concentration for 30 seconds. Now air dried the leaf discs to remove the excess of acetone and placed over wet cotton in petriplate. The adult female mites were released on treated leaf discs and mortality data were recorded after $48 \mathrm{hrs}$. Mites released on leaf treated only with Acetone and tween 20 emulsifier served as control. The mortality data was used for calculation of LC50/LD50 using Maximum Likelihood Programme (MLP). 3.01.

\section{Result and Discussions IR Spectra}

The IR spectra of new organotin compounds were recorded in a Perkin-Elmer spectrophotometer in 4000-200 cm-1range. The IR spectra of compound show absorption bands due to phenyl, p-fluorophenyl and pentafluorophenyl groups. The absorption frequencies due to carbonyl group (both symmetric and asymmetric) in amide have been fully assigned. The Sn-C vibration in case of phenyl and pentafluorophenyl derivatives corresponding to the $y$ mode and appears in the range of $448-460 \mathrm{~cm}-1$. Further characterization of these compounds is in progress for confirmation of structure of the compounds.

\section{Insecticidal Activity}

Insecticidal activity of these compounds was checked against male and female cockroaches (Periplanata americana) and housefly (Musca domestica) using parathion as a standard. The compound shows higher to moderate activity.
The variation in insecticidal activity was due to variation in amide group present in the molecule. The presence of chlorine and bromine groups in ligands enhances the activity. They generally affect on nervous system of the insects and causes unconsciousness resulting to death.

\section{Pesticidal Activity \\ Stomach Toxicity}

The stomach toxicity of these compounds was tested against the larvae of Spodoptera litura using different concentration of the compounds, $0.06 \%, 0.12 \%, 0.25 \%, 0.50 \%$ and $1.00 \%$. The corrected mortality was calculated for the calculation of lethal concentration/lethal dose (LC50). It was found that the compounds show good activity against the larvae of insect pest. The variation in activity was due to presence of different kinds of amide group as a ligand in the molecule. The presence of chlorine and bromine group in ligand increases the activity.

\section{Contact Toxicity}

The contact activity of these compounds was also tested against the larvae of same insect, Spodoptera litura, using different concentration of the compounds. The corrected mortality was calculated to find out the LC50 value of the compounds. It was found that the compounds show better activity against the larvae of insects and shows low value of LC50.

\section{Antifeedant Activity}

The antifeedant activity of these compounds was tested against the insect Spodopters litura larvae using different concentration of the compound and the corrected mortality was calculated to find out the effective concentration (EC50). It was found that compound shows higher to moderate antifeedant activity. It was found that compound having chlorine and bromine groups are more effective against the insects.

\section{Acaricidal Activity}

Acaricidal activity of these compounds was tested against Tetranychus urticae using different concentrations, $0.001 \%, 0.005 \%, 0.05 \%, 0.1 \%$ and $0.5 \%$. The percentage of corrected mortality was calculated to find out the LC50 of these compounds. The results were very surprising that all the compounds show high acaricidal activity against the mite. The presence of different kind of amide group as ligand in organotin compounds enhances the activity.

\section{Acknowledgement}

The authors are thankful to the University Grants Commission, New Delhi(India) for providing fund to our research group(Sanction Letter No.F.61(29)/2008(MRP/NRCB), 26 Feb.2008),Director, NBRI, Lucknow; Director IMTECH, Chandigarh 
for biological activity and Director, RSIC, CDRI for analysis of the compounds.

\section{References}

[1] Dethie V.G., Browne L.B. and Smith C.N. (1960) J. Eco. Entomol. 53, 134-136.

[2] Oatman E.R., McMurtry J.A. and Voth V. (1968) J. Eco. Entomol, 60, 1344.

[3] Chandrashekhar K. and Srinivas N. (2003) J. Entomological, Research, 27(3), 197201.

[4] Bernes J.M. and Magos L. (1968) Organometal. Chem. Rev., 3, 137.

[5] Metcalf R.L. (1995) Organic Insecticides, Interscience, London and New York.

[6] Doak G.O. and Freedman L.D. (1973) Wiley Interscience, New York.

[7] Isman M.B., Koul O., Luczynski A. and Kaminiski J. (1990) J. Agric. Food. Chem. 38, 1406-1411.

[8] Krueger H.R. and O'Brien R.D.(1959) J. Eco. Entomol, 52, 1063.

[9] Barbieri R., Huber F., Silvestru C., Ruisi G., Roosi M., Barone G., Barbieri R. and Paulsen A.( 1999) Appl. Organomet. Chem., 13, 595

[10] Nath Mala, Yadav Rakesh, Eng G., Nguyen Thanh-True and Kumar Ashok(1999) J. Organomet.Chem. 577 (1), 1-8

[11] Chitamber C.R. and Wereley J.P. (1997) J. Biol. Chem., 272, 12151-12157

[12] Collery P., Millart H., Pluot M. and Anghileri L.J. (1986) Anticancer. Res., 6, 10851088

[13] Collery P., Anghileri L.J., Morel M., Tran G., Rinjard P. and Etienne J.C. (1992) Metal ions in biology and medicine, 2, 176-177

[14] Tajmir-Riahi H.A., Naovi M. and Ahmad R. (1990) Toxicol. Appl. Pharmacol; 106, 462-468

[15] Gielen M., Lelieveld P., DeVos D., Pan H., Willem R., Biesemans $M$. and Fiebig H.H. (1992) Inorg. Chem. Acta. 196, 115

[16] Gielen M., Ma H., Bouhdid A., Dalil H., Biesemans M. and Willem R. (1997) Metal Based Drugs, 4, 193

[17] Gielen M., Biesemans M., Elkhloufi A., Piret J.M. and Willem R. (1993) J. Fluorine Chemistry, 64, 279

[18] Kayser F., Biesemans M., Gielen M.and Willem R. (1994) Magn. Reson. Chem., 32,358

[19] Nash R. (1952) Ann. Appl. 41, 652.

[20] Deshmukh S.D. Borle M.N. (1976) Ind. J. Entomol, 37(1), 11-18.

[21] Bhonde S.P., Kapadnis B.P., Deshpande S.P. and Sharma R.N. (2001) J. Med. Aroma. Plant. 24, 721-725. 
Table 1- Physicochemical properties of triorganotin compounds

\begin{tabular}{|l|l|l|l|l|l|l|}
\hline S.N. & Compounds & Formula & $\begin{array}{l}\text { Formula } \\
\text { Weight }\end{array}$ & $\begin{array}{l}\text { Melting } \\
\text { Point }\left(^{\circ} \mathrm{C}\right)\end{array}$ & $\begin{array}{l}\text { Yield } \\
(\%)\end{array}$ & $\begin{array}{l}\text { Solvent for } \\
\text { Crystallization }\end{array}$ \\
\hline 1 & $\left(\mathrm{C}_{6} \mathrm{H}_{5}\right)_{3} \mathrm{Sn}($ succinimide) & $\mathrm{C}_{22} \mathrm{H}_{19} \mathrm{NO}_{2} \mathrm{Sn}$ & 447.71 & 88 & 80 & Pet.-ether $\left(40-60^{\circ} \mathrm{C}\right)$ \\
\hline 2 & $\left(\mathrm{C}_{6} \mathrm{H}_{5}\right)_{3} \mathrm{Sn}$ (phthalimide) & $\mathrm{C}_{26} \mathrm{H}_{19} \mathrm{NO}_{2} \mathrm{Sn}$ & 494.71 & 80 & 85 & Pet.-ether(40-60 $\left.{ }^{\circ} \mathrm{C}\right)$ \\
\hline 3 & $\left(\mathrm{C}_{6} \mathrm{H}_{4} \mathrm{~F}\right)_{3} \mathrm{Sn}($ succinimide) & $\mathrm{C}_{22} \mathrm{H}_{16} \mathrm{NO}_{2} \mathrm{~F}_{3} \mathrm{Sn}$ & 500.71 & 90 & 65 & Pet.-ether(60-80 $\left.{ }^{\circ} \mathrm{C}\right)$ \\
\hline 4 & $\left(\mathrm{C}_{6} \mathrm{H}_{4} \mathrm{~F}\right)_{3} \mathrm{Sn}($ phthalimide) & $\mathrm{C}_{26} \mathrm{H}_{16} \mathrm{NO}_{2} \mathrm{~F}_{3} \mathrm{Sn}$ & 548.71 & 85 & 70 & Pet.-ether(40-60 $\left.{ }^{\circ} \mathrm{C}\right)$ \\
\hline 5 & $\left(\mathrm{C}_{6} \mathrm{~F}_{5}\right)_{3} \mathrm{Sn}($ succinimide) & $\mathrm{C}_{22} \mathrm{H}_{4} \mathrm{NO}_{2} \mathrm{~F}_{15} \mathrm{Sn}$ & 716.71 & 95 & 70 & Pet.-ether(60-80 $\left.{ }^{\circ} \mathrm{C}\right)$ \\
\hline 6 & $\left(\mathrm{C}_{6} \mathrm{~F}_{5}\right)_{3} \mathrm{Sn}$ (phthalimide) & $\mathrm{C}_{26} \mathrm{H}_{4} \mathrm{NO}_{2} \mathrm{~F}_{15} \mathrm{Sn}$ & 764.71 & 90 & 75 & Pet.-ether(40-60 $\left.{ }^{\circ} \mathrm{C}\right)$ \\
\hline
\end{tabular}

Table 2- Analytical data of triorganotin compounds

\begin{tabular}{|l|l|l|l|l|l|l|}
\hline S.N. & Molecular & \multicolumn{3}{|c|}{ Elemental Analysis } & \multicolumn{2}{l|}{ IR (cm $\left.\mathbf{c m}^{-1}\right)$} \\
\cline { 3 - 7 } & Formula & $\mathbf{C}(\%)$ & $\mathbf{H}(\%)$ & $\mathbf{N}(\%)$ & $\mathbf{V}_{\text {asym }}(\mathbf{C O})$ & $\mathbf{V}_{\text {sym }}(\mathbf{C O})$ \\
\hline 1 & $\mathrm{C}_{22} \mathrm{H}_{19} \mathrm{NO}_{2} \mathrm{Sn}$ & 59.09 & 4.25 & 3.13 & $1706 \mathrm{vs}$ & $1308 \mathrm{~ms}$ \\
\hline 2 & $\mathrm{C}_{26} \mathrm{H}_{19} \mathrm{NO}_{2} \mathrm{Sn}$ & 63.06 & 3.84 & 2.82 & $1758 \mathrm{vs}$ & $1354 \mathrm{~ms}$ \\
\hline 3 & $\mathrm{C}_{22} \mathrm{H}_{16} \mathrm{NO}_{2} \mathrm{~F}_{3} \mathrm{Sn}$ & 52.72 & 3.19 & 2.79 & $1726 \mathrm{~ms}$ & $1326 \mathrm{~ms}$ \\
\hline 4 & $\mathrm{C}_{26} \mathrm{H}_{16} \mathrm{NO}_{2} \mathrm{~F}_{3} \mathrm{Sn}$ & 56.86 & 2.91 & 2.55 & $1729 \mathrm{vs}$ & $1329 \mathrm{~ms}$ \\
\hline 5 & $\mathrm{C}_{22} \mathrm{H}_{4} \mathrm{NO}_{2} \mathrm{~F}_{15} \mathrm{Sn}$ & 36.83 & 0.55 & 1.95 & $1732 \mathrm{vs}$ & $1332 \mathrm{~ms}$ \\
\hline 6 & $\mathrm{C}_{26} \mathrm{H}_{4} \mathrm{NO}_{2} \mathrm{~F}_{15} \mathrm{Sn}$ & 40.79 & 0.52 & 1.83 & $1740 \mathrm{~ms}$ & $1338 \mathrm{~ms}$ \\
\hline
\end{tabular}

Table 3- Stomach Toxicity

\begin{tabular}{|l|l|l|l|l|l|}
\hline $\begin{array}{l}\text { S. } \\
\text { No. }\end{array}$ & Compounds & Fiducial limits & Slop \pm S.E. & Chi. Square & $\begin{array}{l}\mathbf{L C}_{50} / \mathbf{L D}_{50} \text { at } \\
\mathbf{2 4} \text { hrs. }\end{array}$ \\
\hline 1. & $\mathrm{C}_{22} \mathrm{H}_{19} \mathrm{NO}_{2} \mathrm{Sn}$ & $1.61-9.55$ & $1.45 \pm 0.17$ & $0.68(3)$ & 2.97 \\
\hline 2. & $\mathrm{C}_{26} \mathrm{H}_{19} \mathrm{NO}_{2} \mathrm{Sn}$ & $0.86-1.99$ & $1.28 \pm 0.16$ & $0.80(3)$ & 1.20 \\
\hline 3. & $\mathrm{C}_{22} \mathrm{H}_{16} \mathrm{NO}_{2} \mathrm{~F}_{3} \mathrm{Sn}$ & $0.49-0.76$ & $1.57 \pm 0.16$ & $2.78(3)$ & 0.60 \\
\hline 4. & $\mathrm{C}_{26} \mathrm{H}_{16} \mathrm{NO}_{2} \mathrm{~F}_{3} \mathrm{Sn}$ & $0.55-0.90$ & $1.48 \pm 0.16$ & $3.37(3)$ & 0.67 \\
\hline 5. & $\mathrm{C}_{22} \mathrm{H}_{4} \mathrm{NO}_{2} \mathrm{~F}_{15} \mathrm{Sn}$ & $0.56-0.97$ & $1.33 \pm 0.15$ & $0.63(3)$ & 0.75 \\
\hline 6. & $\mathrm{C}_{26} \mathrm{H}_{4} \mathrm{NO}_{2} \mathrm{~F}_{15} \mathrm{Sn}$ & $0.85-1.82$ & $1.22 \pm 0.16$ & $0.72(3)$ & 1.12 \\
\hline
\end{tabular}

Table 4- Contact Toxicity

\begin{tabular}{|l|l|l|l|l|l|}
\hline $\begin{array}{c}\text { S. } \\
\text { No. }\end{array}$ & Compounds & Fiducial limits & Slop \pm S.E. & Chi. Square & $\begin{array}{l}\mathbf{L C}_{50} / \mathbf{L D}_{50} \text { at } \\
\mathbf{2 4} \text { hrs. }\end{array}$ \\
\hline 1. & $\mathrm{C}_{22} \mathrm{H}_{19} \mathrm{NO}_{2} \mathrm{Sn}$ & $1.87-12.07$ & $1.09 \pm 0.19$ & $1.62(3)$ & 3.53 \\
\hline 2. & $\mathrm{C}_{26} \mathrm{H}_{19} \mathrm{NO}_{2} \mathrm{Sn}$ & $1.57-9.32$ & $1.07 \pm 0.17$ & $0.72(3)$ & 2.83 \\
\hline 3. & $\mathrm{C}_{22} \mathrm{H}_{16} \mathrm{NO}_{2} \mathrm{~F}_{3} \mathrm{Sn}$ & $0.28-0.40$ & $1.96 \pm 0.16$ & $4.39(3)$ & 0.33 \\
\hline 4. & $\mathrm{C}_{26} \mathrm{H}_{16} \mathrm{NO}_{2} \mathrm{~F}_{3} \mathrm{Sn}$ & $0.39-0.59$ & $1.67 \pm 0.15$ & $5.62(3)$ & 0.46 \\
\hline 5. & $\mathrm{C}_{22} \mathrm{H}_{4} \mathrm{NO}_{2} \mathrm{~F}_{15} \mathrm{Sn}$ & $0.43-0.75$ & $1.63 \pm 0.6$ & $2.94(3)$ & 0.58 \\
\hline 6. & $\mathrm{C}_{26} \mathrm{H}_{4} \mathrm{NO}_{2} \mathrm{~F}_{15} \mathrm{Sn}$ & $1.87-12.07$ & $1.09 \pm 0.19$ & $1.63(3)$ & 3.52 \\
\hline
\end{tabular}


Table 5- Antifeedant Activity

\begin{tabular}{|l|l|l|l|l|l|}
\hline $\begin{array}{l}\text { S. } \\
\text { No. }\end{array}$ & Compounds & $\begin{array}{l}\text { Fiducial } \\
\text { limits }\end{array}$ & Slop \pm S.E. & Chi. Square & $\begin{array}{l}\mathbf{L C}_{50} / \mathbf{L D}_{50} \text { at } \\
\mathbf{2 4} \text { hrs. }\end{array}$ \\
\hline 1. & $\mathrm{C}_{22} \mathrm{H}_{19} \mathrm{NO}_{2} \mathrm{Sn}$ & $0.82-3.41$ & $1.81 \pm 0.14$ & $0.43(3)$ & 1.35 \\
\hline 2. & $\mathrm{C}_{26} \mathrm{H}_{19} \mathrm{NO}_{2} \mathrm{Sn}$ & $0.68-1.72$ & $1.03 \pm 0.14$ & $0.66(3)$ & 0.98 \\
\hline 3. & $\mathrm{C}_{22} \mathrm{H}_{16} \mathrm{NO}_{2} \mathrm{~F}_{3} \mathrm{Sn}$ & $0.43-0.87$ & $1.03 \pm 0.14$ & $0.34(3)$ & 0.58 \\
\hline 4. & $\mathrm{C}_{26} \mathrm{H}_{16} \mathrm{NO}_{2} \mathrm{~F}_{3} \mathrm{Sn}$ & $0.62-1.42$ & $1.06 \pm 0.14$ & $1.07(3)$ & 0.86 \\
\hline 5. & $\mathrm{C}_{22} \mathrm{H}_{4} \mathrm{NO}_{2} \mathrm{~F}_{15} \mathrm{Sn}$ & $0.83-2.33$ & $1.08 \pm 0.15$ & $0.79(3)$ & 1.24 \\
\hline 6. & $\mathrm{C}_{26} \mathrm{H}_{4} \mathrm{NO}_{2} \mathrm{~F}_{15} \mathrm{Sn}$ & $0.72-2.41$ & $0.93 \pm 0.14$ & $0.22(3)$ & 1.13 \\
\hline
\end{tabular}

Table 6- Acaricidal Activity

\begin{tabular}{|l|l|l|l|l|l|}
\hline $\begin{array}{l}\text { S. } \\
\text { No. }\end{array}$ & Compounds & Fiducial limits & Slop \pm S.E. & Chi. Square & $\begin{array}{l}\text { LC }_{50} / \mathbf{L D}_{50} \text { at } \\
\mathbf{2 4} \text { hrs. }\end{array}$ \\
\hline 1. & $\mathrm{C}_{22} \mathrm{H}_{19} \mathrm{NO}_{2} \mathrm{Sn}$ & $0.12-0.30$ & $0.78 \pm 0.08$ & $1.70(3)$ & 0.18 \\
\hline 2. & $\mathrm{C}_{26} \mathrm{H}_{19} \mathrm{NO}_{2} \mathrm{Sn}$ & $0.14-0.31$ & $0.96 \pm 0.09$ & $7.52(3)$ & 0.20 \\
\hline 3. & $\mathrm{C}_{22} \mathrm{H}_{16} \mathrm{NO}_{2} \mathrm{~F}_{3} \mathrm{Sn}$ & $0.05-0.10$ & $0.93 \pm 0.08$ & $13.22(3)$ & 0.06 \\
\hline 4. & $\mathrm{C}_{26} \mathrm{H}_{16} \mathrm{NO}_{2} \mathrm{~F}_{3} \mathrm{Sn}$ & $0.04-0.09$ & $0.69 \pm 0.06$ & $4.64(3)$ & 0.05 \\
\hline 5. & $\mathrm{C}_{22} \mathrm{H}_{4} \mathrm{NO}_{2} \mathrm{~F}_{15} \mathrm{Sn}$ & $0.05-0.09$ & $0.16 \pm 0.09$ & $12.67(3)$ & 0.07 \\
\hline 6. & $\mathrm{C}_{26} \mathrm{H}_{4} \mathrm{NO}_{2} \mathrm{~F}_{15} \mathrm{Sn}$ & $0.07-0.22$ & $0.76 \pm 0.06$ & $5.63(3)$ & 0.14 \\
\hline
\end{tabular}

